\title{
Sustainability of carrot-cowpea intercropping systems through optimization of green manuring and spatial arrangements
}

\author{
Josimar Nogueora da Silva ${ }^{1}$ (i) Francisco Bezerra Neto ${ }^{2}$ (i) Jailma Suerda Silva de Lima ${ }^{2}$ (i) \\ Aridênia Peixoto Chaves ${ }^{2}$ (i) Renato Leandro Costa Nunes ${ }^{3^{*}}$ (i) \\ Gardênia Silvana de Oliveira Rodrigues ${ }^{2}$ (D) Vitor Abel da Silva Lino ${ }^{2}$ (D) Jolinda Mércia de Sá ${ }^{2}$ (D) \\ Elizangela Cabral dos Santos $^{2}$ iD
}

\begin{abstract}
${ }^{1}$ Secretaria de Agricultura e Recursos Hídricos, Belém do Brejo do Cruz, PB, Brasil.
${ }^{2}$ Programa de Pós-graduação em Fitotecnia (PPGF), Universidade Federal Rural do Semi-Árido (UFERSA), Mossoró, RN, Brasil.

${ }_{*}^{3}$ Instituto Federal de Educação, Ciência e Tecnologia do Ceará (IFCE), 62930-000, Limoeiro do Norte, CE, Brasil. E-mail: renatoleandro.ce@hotmail.com. "Corresponding author.

ABSTRACT: One of the biggest challenges in intercropping of two or more crops is to maintain their productivity as that of their sole counterparts. In order to obtain sustainable intercropping systems in a semi-arid environment, this study evaluated the agro-economic advantage and sustainability of intercropped systems of carrot and cowpea, optimizing the green manuring and spatial arrangements. Experiments were conducted in the period from July to October 2017 and 2018, using a randomized complete block design with the treatments arranged in a 4 $x 3$ factorial scheme, with four replications. Treatments included four amounts of $M$. aegyptia incorporated into the soil (20, 35, 50, and 65 $t$ $\mathrm{ha}^{-1}$ on dry basis) with three spatial arrangements $(2: 2,3: 3$, and 4:4) between the components cultures formed from cowpea rows alternated with carrot rows. The agro-economic advantage indices evaluated in the intercropping systems were: land equivalent ratio (LER), area-time equivalent ratio (ATER), score of the canonical variable (Z), actual yield loss (AYL), intercropping advantage (IA), gross income (GI), net income (NI), rate of return (RR), and profit margin (PM). The highest agro-economic advantages of the carrot and cowpea intercropping were obtained for LER, ATER, NI, and RR of 2.60, 4.16, US\$ 8,720.99 ha $\mathrm{h}^{-1}$, and US\$2.21, respectively, for M. aegyptia biomass amounts of 46.42, 47.82, 32.60 and 31.51 tha $\mathrm{h}^{-1}$ added to the soil. The 2: 2 spatial arrangement was the one with the best productive performance, with higher net income and rate of return in the intercropping of carrot-cowpea.
\end{abstract}

Key words: agro-economic efficiency, competitive ability, Daucus carota, Merremia aegyptia, Vigna unguiculata.

Sustentabilidade de sistemas consorciados de cenoura e feijão-caupi por meio da otimização da adubação verde e arranjos espaciais

RESUMO: Um dos maiores desafios no consórcio de duas ou mais culturas é manter sua produtividade como a de suas únicas contrapartes. Com o objetivo de obter sistemas de consórcio sustentáveis em ambiente semiárido, este estudo avaliou vantagem agroeconômica e a sustentabilidade de sistemas consorciados de cenoura e feijão-caupi, otimizando a adubação verde e os arranjos espaciais. Experimentos foram conduzidos no periodo de julho a outubro de 2017 e 2018, em delineamento de blocos ao acaso, com os tratamentos dispostos em esquema fatorial $4 \times 3$, com quatro repetições. Os tratamentos incluíram quatro quantidades de M. aegyptia incorporadas ao solo (20, 35, 50 e 65 t ha $\mathrm{H}^{-1}$ em base seca) com três arranjos espaciais (2: 2, 3: 3 e 4: 4) entre as culturas componentes formadas a partir de fileiras de feijãocaupi alternadas com fileiras de cenoura. Os indices de vantagem agroeconômica avaliados nos sistemas de consorciação foram: indice de uso eficiente da terra (UET), razão de área equivalente no tempo (RAET), escore da variável canônica (Z), perda de rendimento real (PRR), vantagem do consórcio (VC), renda bruta $(R B)$, renda líquida (RL), taxa de retorno (TR) e margem de lucro (ML). As maiores vantagens agroeconômicas do consórcio de cenoura e feijão-caupi foram obtidas para UET, RAET, RL e TR de 2,60, 4,16, US\$ 8.720,99 ha-1 e US\$ 2,21, respectivamente, para as quantidades de biomassa de $M$. aegyptia de 46,42, 47,82, 32,60 e 31,51 tha ${ }^{-1}$, adicionadas ao solo. O arranjo espacial 2: 2 foi o de melhor desempenho produtivo, com maior receita líquida e taxa de retorno no consórcio entre feijão-caupi e cenoura. Palavras-chave: eficiência agroeconômica, habilidade competitiva, Daucus carota, Merremia aegyptia, Vigna unguiculata.

\section{INTRODUCTION}

Intercropping has provided sustainable farming systems due to gains in crop productivity and a better use of the available environmental resources.
This is especially the case when the associated crops have some complementarity, which may be, more or less, depending on the management of the system. However, the bio-agroeconomic efficiency of such systems is directly linked to the crop species and 
the production factors, including green fertilization, spatial arrangements, and cropping years.

Green fertilization promoted several benefits to the soil, mainly because it provides a greater coverage, preservation, restoration, and increase in soil organic matter contents, with a higher biomass production potential and nutrient absorption and accumulation capacity. These factors are of great importance to the soil-plant system because they are related to nutrient cycling, increasing nutrient availability to cultivated plants (ALBUQUERQUE et al., 2013).

Green fertilization can provide several advantages to cropping systems, with the selection of the green manure species being particularly important in terms of the climate as well as the soil and the crop management system, especially in intercropping systems (SOUSA et al., 2018). Thus, green fertilization in crop systems with food crops and vegetables with spontaneous species of the Caatinga biome is an excellent strategy to increase the amount of nutrients in the soil (BEZERRA NETO et al., 2014), because these species present the same benefits as the species introduced in relation to biomass production and nutrient cycling, thus favoring the soil biota and positively contributing to successive agricultural crops (FAVERO et al., 2000).

Spatial arrangements, when properly delineated in intercropping systems, allow cultures to interact with each other, thereby maximizing productivity. This maximization in production occurs when the spatial arrangement provides a more uniform distribution of plants per area, allowing a better use of light, water, and nutrients (BRACHTVOGEL et al., 2009).

Conversely, green manuring can promote improvements in soil characteristics and fertility, and the spatial arrangements can maximize the use of these environmental resources. Previous studies in this area have focused on providing more accurate information for our understanding of the interactive process between these production factors and the individual ability that each culture establishes in this cropping system, using indicators of bioagroeconomic efficiency, such as land equivalent ratio, area time equivalent ratio (DINIZ et al., 2017), actual yield loss, intercropping advantage (MORAES et al., 2018), score of the canonical variable (PIMENTEL-GOMES \& GARCIA, 2002), gross income, net income, rate of return, and profit margin (CARVALHO et al., 2018; SILVA et al., 2017).

In this context, the objective of this study was to attribute sustainability to intercropped systems of carrot and cowpea by optimizing green manuring and spatial arrangements in semi-arid conditions.

\section{MATERIALS AND METHODS}

Two field experiments were conducted in different experimental areas from July to October 2017 and 2018 at the Rafael Fernandes Experimental Farm, located in the Lagoinha district, $20 \mathrm{~km}$ from Mossoró-RN, Brazil (5' 11 ' 31 ' 'S, $37^{\circ} 20$ '40 “W, $18 \mathrm{~m}$ above sea level). According to the Köppen classification, the climate is "BShw", semi-arid, dry and hot, with a dry season from June to January and a rainy season from February to May (OLIVEIRA et al., 2012). The soil of the experimental areas was classified as a typical dystrophic Red Argisol (RÊGO et al., 2016). During the experimental periods, precipitation was $0 \mathrm{~mm}$ in the two cropping years; average temperature and relative air humidity were $27.3^{\circ} \mathrm{C}$ and $62.2 \%$; respectively, for 2017 and $27.2{ }^{\circ} \mathrm{C}$ and $64.9 \%$, respectively, for 2018 .

Prior to the experiment, soil samples were taken from at depth of 0-20 cm, air-dried, and sieved to pass a 2-mm sieve. Subsequently, the samples were analyzed in the Laboratory of Soil Fertility and Chemistry of the Universidade Federal Rural do Semi-Árido (UFERSA), obtaining the following results (Table 1).

A randomized complete block design was used, with the treatments arranged in a $4 \times 3$ factorial scheme, with four replications. The treatments consisted of the combination of four amounts of $M$. aegyptia incorporated into the soil $(20,35$, 50 , and $65 \mathrm{t} \mathrm{ha}^{-1}$ on dry basis), with three planting spatial arrangements $(2: 2,3: 3$, and $4: 4)$ between the components cultures formed from rows of cowpea alternated with carrot rows.

The intercropping was established in alternating rows, using $50 \%$ of the area for carrot and the other $50 \%$ of the area for cowpea, flanked by two border rows of each crop on each side. The total areas of the plots in the $2: 2,3: 3$, and $4: 4$ arrangements were $2.40,3.00$, and $3.60 \mathrm{~m}^{2}$, respectively, with harvest areas of $1.00,1.50$, and $2.00 \mathrm{~m}^{2}$, containing 50,75, and 100 carrot plants and 20,30, and 40 cowpea plants, at spacings of $0.25 \times 0.04 \mathrm{~m}$ and $0.25 \times$ $0.10 \mathrm{~m}$; respectively, according to the methodology recommended by FAVACHO et al. (2017).

In each block, plots in monocropping of the cowpea and carrot crops were planted to obtain the agro-economic advantage indices of the intercropping. The crop monocultures were established with the planting of six rows per plot for each crop, with a total area of $1.44 \mathrm{~m}^{2}$ and a harvest area of $0.80 \mathrm{~m}^{2}$, with a spacing of $0.20 \times 0.10 \mathrm{~m}$ for carrot. For cowpea, the total area was $3.60 \mathrm{~m}^{2}$, with 
Table 1 - Chemical analysis of the soil before incorporation of $M$. aegyptia biomass in the first and second cropping year in the experimental areas.

\begin{tabular}{|c|c|c|c|c|c|c|c|c|c|c|c|c|c|}
\hline \multirow{3}{*}{$\begin{array}{l}\text { Experimental } \\
\text { areas } \\
1\end{array}$} & \multirow{3}{*}{$\begin{array}{c}\mathrm{N} \\
\mathrm{g} \mathrm{kg}^{-1} \\
0.51\end{array}$} & \multirow{3}{*}{$\begin{array}{c}\mathrm{pH} \\
\text { (water) } \\
8.20\end{array}$} & \multirow{3}{*}{$\begin{array}{c}\mathrm{EC} \\
\mathrm{ds} \mathrm{m}^{-1} \\
1.77\end{array}$} & \multirow{3}{*}{$\begin{array}{l}\mathrm{OM} \\
\mathrm{g} \mathrm{kg}^{-1} \\
3.64\end{array}$} & $\mathrm{P}$ & $\mathrm{K}^{+}$ & $\mathrm{Na}^{+}$ & $\mathrm{Ca}^{2+}$ & $\mathrm{Mg}^{2+}$ & $\mathrm{Cu}$ & $\mathrm{Fe}$ & $\mathrm{Mn}$ & $\mathrm{Zn}$ \\
\hline & & & & & \multicolumn{3}{|c|}{----------mg dm'---------- } & \multicolumn{2}{|c|}{$--\mathrm{cmol}_{\mathrm{c}} \mathrm{dm}^{-3}--$} & \multicolumn{4}{|c|}{ 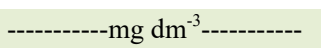 } \\
\hline & & & & & 10.30 & 57.20 & 11.60 & 2.05 & 0.60 & 0.19 & 2.03 & 10.43 & 6.21 \\
\hline 2 & 0.35 & 8.10 & 0.24 & 4.97 & 22.80 & 64.70 & 13.70 & 3.28 & 0.78 & 0.10 & 1.91 & 11.67 & 2.63 \\
\hline
\end{tabular}

N- Nitrogen; pH- Hydrogenionic potential; EC- Electrical conductivity; OM- Organic matter; P- Phosphorus; $\mathrm{K}^{+}-\mathrm{Potassium}$; Na ${ }^{+}$ Sodium; $\mathrm{Ca}^{2+}$ - Calcium; $\mathrm{Mg}^{2+}$ - Magnesium; $\mathrm{Cu}$ - Copper; Fe- Iron; Mn- Manganese and $\mathrm{Zn}-\mathrm{Zinc}$.

a harvest area of $2.00 \mathrm{~m}^{2}$, at a spacing of $0.50 \times 0.10$ $\mathrm{m}$, according to the methodology recommended by BEZERRA NETO et al. (2014) and VIEIRA et al. (2018) for this region. The harvest area of these crops was derived from the four central rows of carrot and cowpea plants in each plot, excluding the first and last plants of each row.

The experimental areas were mechanically cleaned with a tractor with a coupled plow, followed by harrowing and mechanized lifting of the beds. After this, a solarization in pre-planting was performed with transparent plastic, Vulca Brilho Bril Flex, of 30 microns for 45 days to control nematodes and phytoparasites in the $0-20-\mathrm{cm}$ soil layer to protect the plant roots.

The $M$. aegyptia used as green manure was collected near Mossoró, RN, Brazil, before the onset of flowering. After harvesting, the plants were crushed in a conventional forage machine, obtaining fragmented particles of around 2.0 to $3.0 \mathrm{~cm}$. After crushing, the material was dried in the sun until reaching a moisture content of approximately $10 \%$; subsequently, a sample was analyzed in the laboratory, yielding the following results shown in the table 2 .

Two incorporations were made with the different green manure amounts studied. The first incorporation was carried out 20 days before planting, using $50 \%$ of the $M$. aegyptia; the remaining $50 \%$ were incorporated at 45 days after planting, according to the methodology used by FAVACHO et al. (2017). The amounts of $M$. aegyptia biomass used in the monocropping of the crops, carrot and cowpea, were those optimized and recommended based on previous research in this region (BEZERRA NETO et al., 2014).

Carrot and cowpea were sown simultaneously on July 14 in 2017 and 2018. The carrot cultivar 'Brasília' and the cowpea cultivar 'BRS Tumucumaque' sown are recommended for cultivation in the Brazilian Northeast. Carrot rows were thinned at 18 days after sowing (DAS) and cowpea rows at $12 \mathrm{DAS}$, leaving one plant per hole. Weeds were controlled manually whenever necessary to avoid competition for water, light, and nutrients. Cowpea was harvested from 55 to 67 DAS in 2017 and from 57 to 67 DAS in 2018, while carrot was harvested at 96 and 95 DAS in 2017 and 2018, respectively.

The plots were irrigated with a micro sprinkler system; irrigation was divided in two applications (morning and afternoon) to facilitate soil microbial activity and; consequently, favor the decomposition of the plant material.

The variables evaluated in the intercropping systems were: commercial productivity of carrot

Table 2 - Macronutrient contents in the M. aegyptia biomass and $\mathrm{C} / \mathrm{N}$ ratio in the first and second cropping year.

\begin{tabular}{|c|c|c|c|c|c|c|}
\hline \multirow[t]{2}{*}{ Cropping years } & \multicolumn{5}{|c|}{--1he green manure $\left(\mathrm{g} \mathrm{kg}^{-1}\right)--1$} & \multirow[t]{2}{*}{$\mathrm{C} / \mathrm{N}$ ratio } \\
\hline & $\mathrm{N}$ & $\mathrm{P}$ & K & $\mathrm{Ca}$ & $\mathrm{Mg}$ & \\
\hline 1 & 15.30 & 4.00 & 15.70 & 9.30 & 7.03 & $25: 1$ \\
\hline 2 & 16.60 & 2.79 & 20.80 & 19.35 & 7.07 & $25: 1$ \\
\hline
\end{tabular}

N- Nitrogen; P- Phosphorus; K- Potassium; Ca- Calcium and Mg- Magnesium. 
roots, which was quantified by the fresh mass of the long, medium, and short roots of the plot area, considering only roots free of cracks, bifurcations, nematodes, and mechanical damage, expressed in $\mathrm{t}$ $\mathrm{ha}^{-1}$, and the yield of cowpea green grains, determined by the weight of green grains obtained in the harvest area of each plot and expressed in $\mathrm{tha}^{-1}$.

Production costs were calculated and analyzed at the end of the production process in October 2017 and 2018, based on the total expenditures per hectare of a cultivated area, deriving from each amount of $M$. aegyptia within each spatial arrangement (Table 3). Revenues obtained in each treatment were obtained through the value of the production of one hectare that was measured, according to the prices paid to the producer in October 2017 and 2018, corresponding to $\mathrm{R} \$ 1.80$ $\mathrm{kg}^{-1}$ for carrot commercial roots of the three types: long, medium, and short in both cropping years and to $\mathrm{R} \$ 5.60 \mathrm{~kg}^{-1}$ and $\mathrm{R} \$ 5.50 \mathrm{~kg}^{-1}$ for cowpea in 2017 and 2018, respectively. The exchange rate of the US dollar on October 2018 was $\$ 1=\mathrm{R} \$ 3.85$.

The agro-economic advantage indices evaluated in the intercropping systems were: land equivalent ratio (LER), area-time equivalent ratio (ATER), score of the canonical variable $(\mathrm{Z})$, actual

Table 3 - Production total costs of carrot intercropped with cowpea in two cropping years under different M. aegyptia biomass amounts and spatial arrangements.

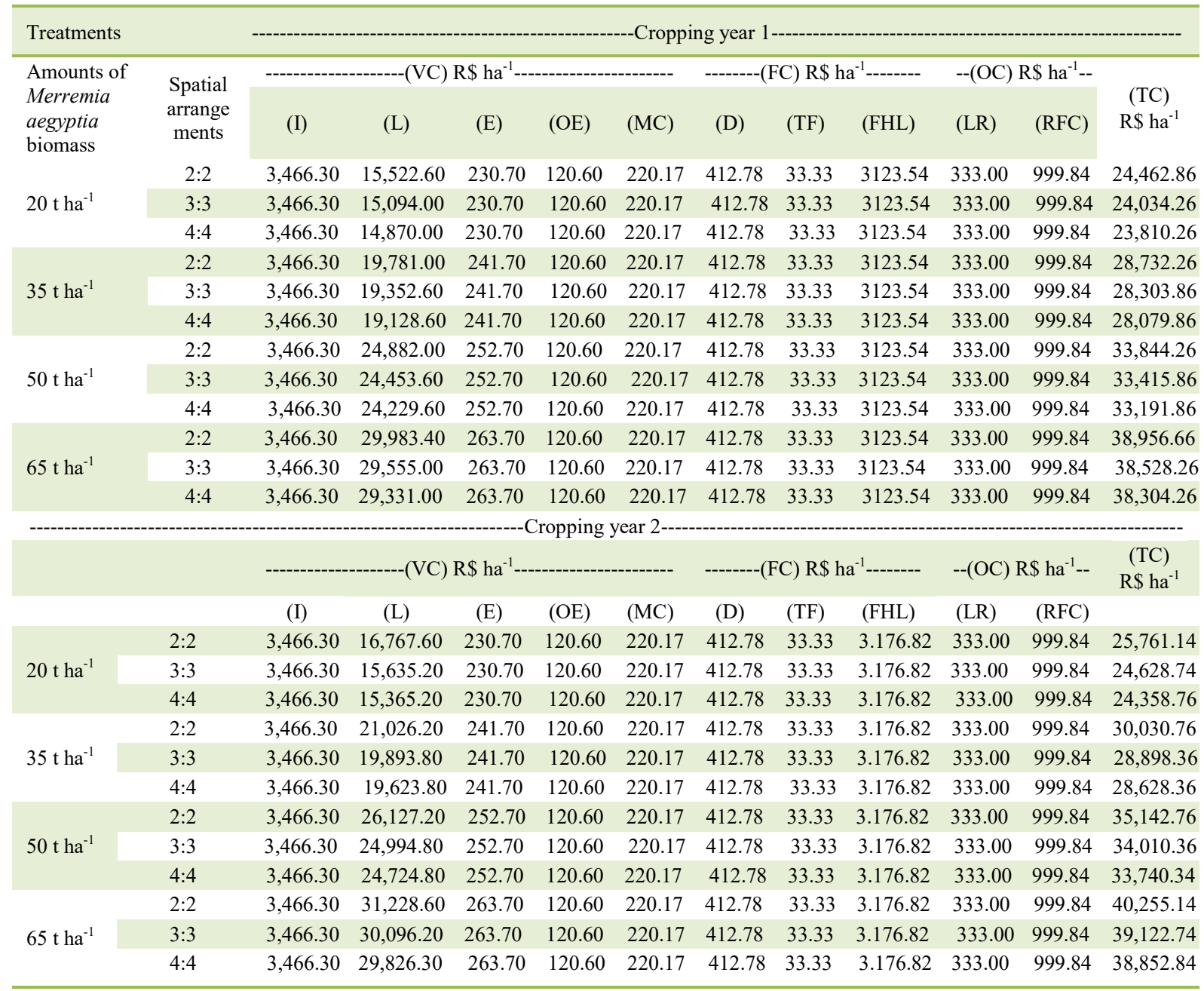

VC - Variable costs, I - Inputs, L - Labor, E - Energy, OE - Other expenses, MC - Maintenance and conservation, FC - Fixed costs, D Depreciation, TF - Taxes and fees, FHL - Fixed hand labor, OC - Opportunity costs, LR - Land remuneration, RFC - Remuneration of fixed capital and TC - Total costs. 
yield loss (AYL), intercropping advantage (IA), gross income (GI), net income (NI), rate of return (RR), and profit margin (PM).

The land equivalent ratio (LER) is defined as the relative area of land under isolated planting conditions and required to provide the productivities reached in the intercropping system (DINIZ et al., 2017). It was obtained by the following expression: $\mathrm{LER}=\left(\mathrm{Y}_{\mathrm{tc}} / \mathrm{Y}_{\mathrm{t}}\right)+\left(\mathrm{Y}_{\mathrm{ct}} / \mathrm{Y}_{\mathrm{c}}\right)$

where $\mathrm{Y}_{\mathrm{tc}}=$ carrot productivity in intercropping with cowpea, $\mathrm{Y}_{\mathrm{t}}=$ productivity of the carrot in single cropping, $\mathrm{Y}_{\mathrm{ct}}=$ yield of green grains of cowpea in intercropping with carrot, $Y_{c}=$ yield of green grains of cowpea in single cropping. If LER $>1$, there is a productive advantage, and if LER $\leq 1$, there is no productive advantage.

The area-time equivalent ratio was obtained according to the methodology used by DINIZ et al. (2017), taking into account the time in relation to the crops and the intercropping system, based on the expression ATER $=\left[\left(\operatorname{LER}_{t} \mathrm{x} \mathrm{T}_{\mathrm{t}}\right)+\left(\mathrm{LER}_{\mathrm{c}}\right.\right.$ $\left.\left.\mathrm{x} \mathrm{T}_{\mathrm{c}}\right)\right] / \mathrm{T}$

where LER $_{t}$ and LER represent the partial land equivalent ratios of the carrot $\left(_{t}\right)$ and cowpea $\left({ }_{c}\right)$ crops, " $\mathrm{T}_{t}$ " represents the number of days from planting to the harvest of crop ' $t$ ', and " $T$ " 'represents the number of days of planting until the harvest of crop 'c'. Here, " $T$ " represents the total time of the intercropping between the crops ' $t$ ' and ' $c$ '. If ATER $>1$, there is a productive advantage, while ATER $\leq 1$, there is no productive advantage.

The score of the canonical variable $(Z)$ was obtained through multivariate analysis of variance of the commercial productivity of carrot roots and the yield of green grains of cowpea.

The actual yield loss was obtained according to BANIK (1996), using the following expression: $\mathrm{AYL}=\left[\left\{\left(\mathrm{Y}_{\mathrm{tc}} / \mathrm{Z}_{\mathrm{tc}}\right) /\left(\mathrm{Y}_{\mathrm{t}} / \mathrm{Z}_{\mathrm{t}}\right)\right\}-1\right]+\left[\left\{\left(\mathrm{Y}_{\mathrm{ct}} /\right.\right.\right.$ $\left.\left.\left.\mathrm{Z}_{\mathrm{ct}}\right) /\left(\mathrm{Y}_{\mathrm{c}} / \mathrm{Z}_{\mathrm{c}}\right)\right\}-1\right]$ where: $Y_{\mathrm{cvc}}$ represents the commercial productivity of carrot roots in intercropping with cowpea, $Z_{\text {tc }}$ is the proportion of carrot planting in intercropping with cowpea, $Y_{t}$ is the commercial productivity of carrot roots in single cropping, $Z_{t}$ is the proportion of carrot planting in single cropping, $Y_{c t}$ represents the yield of green grains of cowpea in intercropping with carrot, $Z_{\mathrm{ct}}$ is the proportion of cowpea planted in intercropping with carrot, $\mathrm{Y}_{\mathrm{c}}$ is the yield of green grains of cowpea in single cropping, and $\mathrm{Z}_{\mathrm{c}}$ represents the proportion of cowpea planted in singe cropping. If AYL $>0$, there is an accumulated advantage of the intercropping system in relation to the monoculture, while AYL $\leq 0$, indicates a disadvantage of the intercropping system.
The intercropping advantage (IA) was determined according to BANIK et al. (2000), defined by the following expression: $\mathrm{IA}=\mathrm{AYL}_{\mathrm{t}} \times \mathrm{P}_{\mathrm{t}}+$ $\mathrm{AYL}_{\mathrm{c}} \times \mathrm{P}$ where $\mathrm{AYL}_{\mathrm{t}}$ and $\mathrm{AYL}$ represent the actual yield losses of the carrot and cowpea, respectively, and $P_{t}$ and $\mathrm{P}_{c}$ are the prices of the carrot and cowpea in $\mathrm{R} \$$ $\mathrm{kg}^{-1}$, referring to October 2017 and 2018, respectively. US $\$ 1=\mathrm{R} \$ 3.85$, as on October 2018. If IA $>0$, there is an advantage of the intercropping system in relation to the monoculture, while IA $\leq 0$, indicates a disadvantage of the intercropping system.

The gross income (GI) was obtained by multiplying the crop productivities in each treatment by the price paid to the producer at the market level in the region in October 2017 and 2018. The net income (NI) was calculated by subtracting from gross income the total costs of production (TC) from inputs and services (NI = GI - TC). The rate of return (RR) was obtained by the ratio between gross income and total cost, which corresponds to how many reals are obtained for each applied real $(\mathrm{RR}=\mathrm{RB} / \mathrm{TC})$, and the profit margin (PM) was obtained by the ratio between net income and gross income, expressed as a percentage $[\mathrm{PM}=(\mathrm{NI} / \mathrm{GI}) \times 100]$, according to the methodology of SILVA et al. (2017).

Univariate and combined analyses of variance were performed on the agro-economic efficiency indices evaluated in the carrot and cowpea intercropping systems, using the SISVAR software (FERREIRA, 2011). The Tukey test was used to compare the means between the spatial arrangements and $\mathrm{F}$ test for comparison between cropping years. The regression curves were adjusted to estimate the behavior of the agro-economic indices determined as a function of the amounts of $M$. aegyptia biomass incorporated into the soil, using the Table Curve software version 3.0 (JANDEL SCIENTIFIC, 1991).

\section{RESULTS AND DISCUSSION}

The agronomic advantage of the intercropped systems of carrot and cowpea as a function of green manuring and spatial arrangements was assessed through productivity and competition indices, while the economic advantage was estimated through economic indicators.

\section{Agronomic advantage}

This agronomic advantage of the intercropping systems was evaluated through the following productivity and competition indices: LER, ATER, Z, AYL, and IA. These indices are not 
only intended to estimate the effect of competition between the different component crops that make up the system, but also to assess which system is best at managing environmental resources to provide the highest productivity. In particular, LER and ATER indicated the efficiency of intercropping for using the resources of the environment compared with monocropping. When the LER and ATER are greater than one the intercropping favors the growth and yield of the crops.

Positive values of AYL, IA, and Z indicate advantage of intercropping; i.e., they provided a quantitative assessment of the advantage accumulated in any system of intercropping in comparison to the respective monocropping. The higher the value, the greater the intercropping's advantage. The magnitude of these indices reflects the nature of the competition of the crops and system productivity.

According to the results of the analysis of variance of the agronomic advantage indices of the carrot and cowpea intercropping system, there was significant interaction between cropping years and spatial arrangements for all indices evaluated (Table 4).

Partitioning the cropping years within each spatial arrangement, we observed a greater land equivalent ratio (LER), actual yield loss (AYL), and intercropping advantage (IA) in the second year in all spatial arrangements. A different result was observed for the area-time equivalent ratio (ATER), with higher average values in the first cropping year in all spatial arrangements. Regarding the score of the canonical variable $(Z)$, the highest mean value was recorded in the second cropping year in the 2:2 spatial arrangement; however, in the other spatial arrangements, no significant differences were observed between the mean values of the two cropping years (Table 5).

Conversely, studying the spatial arrangements within each cropping year in all the agronomic indicators studied (LER, ATER, Z, AYL, and IA), the values in the 2:2 spatial arrangement were higher in both cropping years (Table 5).

There was also a significant interaction between the spatial arrangements and the amounts of $M$. aegyptia biomass in terms of the agronomic efficiency indices analyzed (Table 4), except for the actual yield loss (AYL). Studying the spatial arrangements within each amount of $M$. aegyptia biomass, the highest agronomic efficiency index values were recorded in the spatial arrangement 2:2 (Table 5).

Unlike, partitioning the interaction, amounts of $M$. aegyptia biomass within each spatial arrangement for the agronomic indices LER, ATER, $Z$, and IA an optimization of these indices was registered as a function of the green manure amounts in each planting arrangement (Figures 1A, 1B, 1C and 1D). An increasing polynomial behavior was recorded with the amounts of green manure in the $2: 2$, $3: 3$, and $4: 4$ arrangements, up to the maximum values of LER of 2.60, 1.80, and 1.58, respectively, for the amounts of $M$. aegyptia biomass of 46.42, 36.30, and $54.38 \mathrm{t} \mathrm{ha}^{-1}$ and up to the maximum ATER values of $4.16,3.36$, and 3.04 for the amounts of 47.82, 44.00, and $56.78 \mathrm{t} \mathrm{ha}^{-1}$ of $M$. aegyptia incorporated into the soil, with a subsequent decrease (Figures 1A and 1B).

This same upward polynomial behavior in relation to increasing amounts of $M$. aegyptia biomass was also recorded for the score of the canonical

Table 4 - F values for the land equivalent ratio (LER), area-time equivalent ratio (ATER), score of the canonical variable (Z), actual yield loss (AYL), and intercropping advantage (IA) of carrot intercropped with cowpea in two cropping years under different M. aegyptia biomass amounts and spatial arrangements.

\begin{tabular}{|c|c|c|c|c|c|c|}
\hline Sources of variation & DF & LER & ATER & $\mathrm{Z}$ & AYL & IA \\
\hline Blocks (Cropping years) & 6 & $0.74^{\mathrm{ns}}$ & $363.99^{* *}$ & $0.72^{\mathrm{ns}}$ & $0.90^{\mathrm{ns}}$ & $0.88^{\mathrm{ns}}$ \\
\hline Cropping years $(\mathrm{Y})$ & 1 & $252.50^{* *}$ & $1869.45^{* *}$ & $24.57^{* *}$ & $83.37^{* *}$ & $81.27^{* *}$ \\
\hline Amounts of $M$. aegyptia biomass (Q) & 3 & $37.00^{* *}$ & $23.85^{* *}$ & $38.68^{* *}$ & $37.88^{* *}$ & $37.06^{* *}$ \\
\hline Spatial arrangements (A) & 2 & $106.96^{* *}$ & $79.35^{* *}$ & $120.09^{* *}$ & $105.52^{* *}$ & $123.86^{* *}$ \\
\hline $\mathrm{Y} \times \mathrm{Q}$ & 3 & $0.19^{\mathrm{ns}}$ & $1.67^{\mathrm{ns}}$ & $1.74^{\mathrm{ns}}$ & $2.03^{\mathrm{ns}}$ & $2.14^{\mathrm{ns}}$ \\
\hline $\mathrm{Y} \times \mathrm{A}$ & 2 & $46.33^{* *}$ & $8.65^{* *}$ & $33.10^{* *}$ & $13.06^{* *}$ & $15.94^{* *}$ \\
\hline Q x A & 6 & $2.75^{*}$ & $2.26^{*}$ & $3.75^{* *}$ & $2.12^{\mathrm{ns}}$ & $2.61^{*}$ \\
\hline$Y \times Q \times A$ & 6 & $0.46^{\mathrm{ns}}$ & $0.49^{\mathrm{ns}}$ & $0.58^{\mathrm{ns}}$ & $0.53^{\mathrm{ns}}$ & $1.06^{\mathrm{ns}}$ \\
\hline CV $(\%)$ & - & 9.87 & 7.06 & 14.61 & 26.23 & 30.88 \\
\hline
\end{tabular}

${ }^{* *}=\mathrm{P}<0.01 ;{ }^{*}=\mathrm{P}<0.05 ; \mathrm{ns}=\mathrm{P} \geq 0.05$. 
Table 5 - Mean values for land equivalent ratio (LER), area-time equivalent ratio (ATER), score of the canonical variable (Z), actual yield loss (AYL), and intercropping advantage (IA) of carrot intercropped with cowpea in two cropping years under different $M$. aegyptia biomass amounts and spatial arrangements.

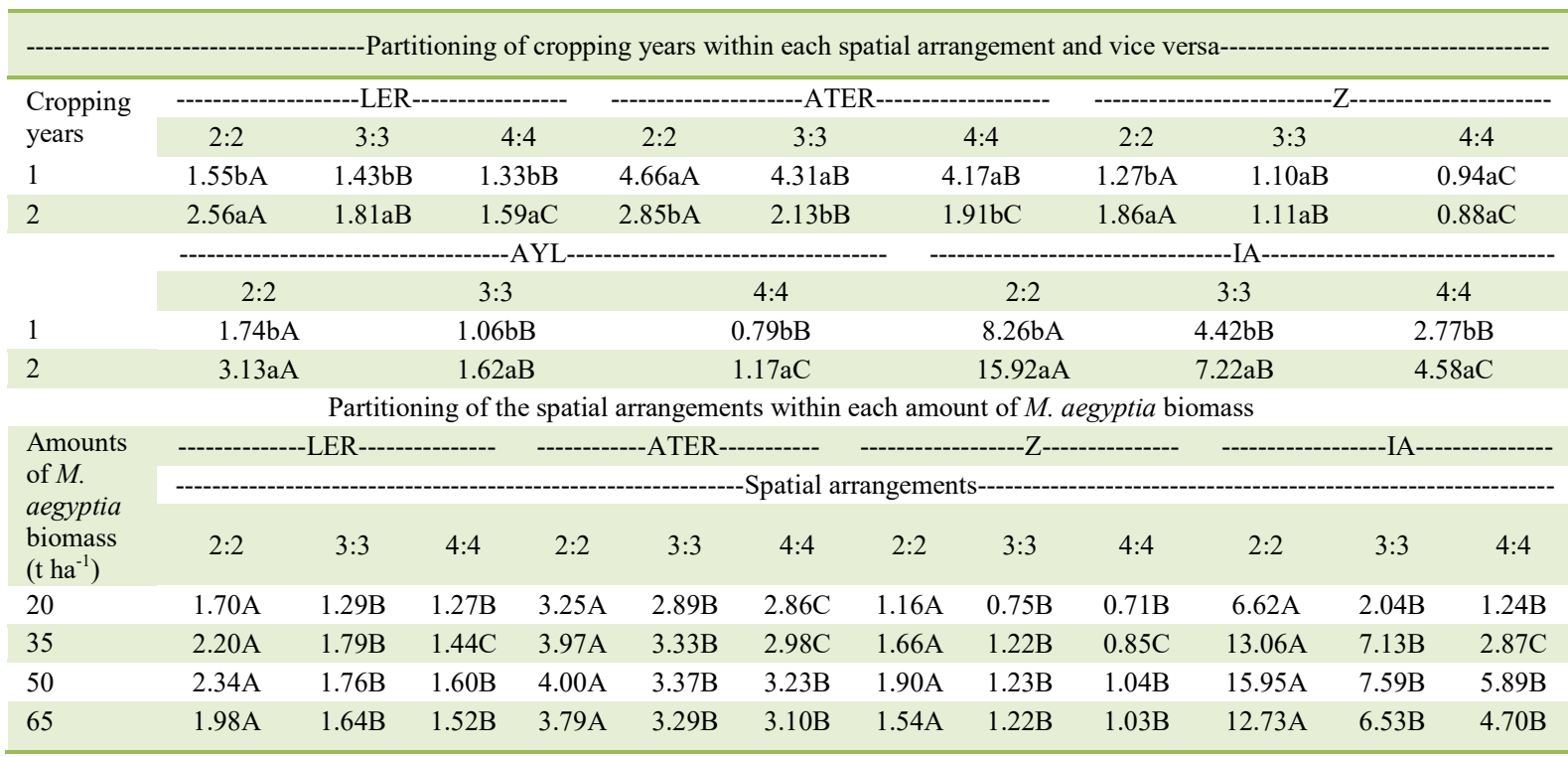

${ }^{*}$ Means followed by different lowercase letters within one column or uppercase letters within one row differ statistically from each other by Tukey or F test at the $5 \%$ probability level.

variable $\mathrm{Z}$ and for the intercropping advantage in the $2: 2,3: 3$, and $4: 4$ arrangements, with maximum $\mathrm{Z}$ values of $2.11,1.24$, and 1.16 , respectively, for the biomass amounts of 48.12, 45.41, and $58.42 \mathrm{t} \mathrm{ha}^{-1}$ and up to the maximum IA values of 14.94, 7.92, and 6.64 for the amounts of $M$. aegyptia biomass of 49.09, 43.44 , and $54.63 \mathrm{t} \mathrm{ha}^{-1}$, with a subsequent decrease (Figures 1C and 1D).

Regarding the AYL, an upward polynomial behavior was observed with increasing $M$. aegyptia biomass levels, with a maximum value of 2.06 for a biomass amount of $48.57 \mathrm{t} \mathrm{ha}^{-1}$, with a subsequent decrease (Figure 1C).

Production of food crops and vegetables in intercropping systems in the northeastern semiarid region is being practiced using the production factors spatial arrangement, green manure amount, and cropping year, among others, to increase crop productivity by reasonably exploring the environmental resources and by promoting a better ecosystem balance. Thus, the selection of the optimum amount of green manure and the most suitable spatial arrangement in the best cropping year are important for the agro-economic efficiency of the intercropping system.
The highest values observed for the agronomic efficiency indicators (LER, Z, AYL, and IA) in the second cropping year are probably due to the concentration of phosphorus $(\mathrm{P})$ present in the soil during the cropping year, with concentrations of $22.80 \mathrm{mg} \mathrm{dm}{ }^{-3}$, higher than those in the first cropping year $\left(10.30 \mathrm{mg} \mathrm{dm}^{-3}\right)$. This higher amount of $\mathrm{P}$ in the second cropping year may have enhanced the development and productive performance of the carrot and cowpea crops.

Another factor that may have provided greater agronomic efficiency during this cropping year is the higher content of soil organic matter (4.97 $\mathrm{g} \mathrm{kg}^{-1}$ ), while that in the first cropping year, the soil organic matter level was lower $\left(3.64 \mathrm{~g} \mathrm{~kg}^{-1}\right)$. Due to the organic fertilization to improve the soil structure, aerate the soil, and increase the storage capacity for soil moisture, the conditions were more favorable for plant growth, resulting in a higher productive capacity.

Regarding the spatial geometry of the intercropping systems, the best results were recorded when the carrot and cowpea plants were planted in the 2:2 spatial arrangement, irrespective of the efficiency index. Most likely, this is because of the smaller inter- and intraspecific competition between 

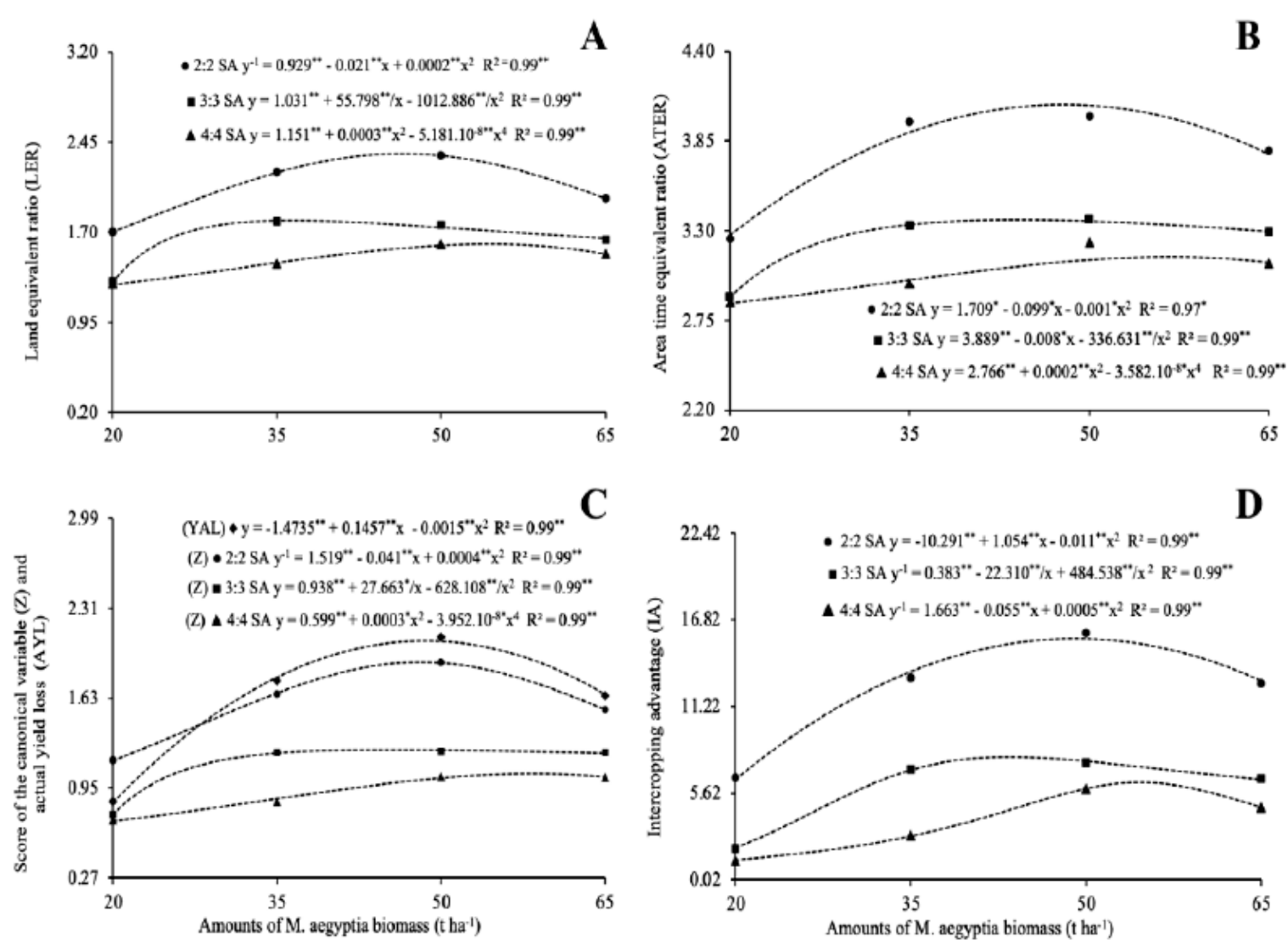

Figure 1 - Land equivalent ratio (A), area-time equivalent ratio (B), score of the canonical variable, actual yield loss (C), and intercropping advantage (D) of the carrot intercropped with cowpea as a function of the amounts of M. aegyptia biomass incorporated into the soil in different spatial arrangements.

the carrot and cowpea plants, which allowed a greater crop productivity of the crops due to a better use of water, light, nutrients, and $\mathrm{CO}_{2}$. In this way, these crops could transform their productive capacity into agro-economic efficiency.

Generally, in intercropping systems, species differ in height and leaf distribution, among other morphological characteristics, which can cause plants to compete for light, water, and nutrients (PINTO \& PINTO, 2012). Thus, the most suitable spatial arrangement is one that provides better plant configuration, resulting in higher management efficiency and better use of environmental resources (BEZERRA et al., 2014).

The highest recorded LER value was 2.56, obtained in the second cropping year in the 2:2 spatial arrangement. This value portrays the positive effect in the use of this spatial arrangement in this particular cropping year in terms of the production of food per unit area. This result expressed a greater viability of this cultivation system, indicating a more efficient use of the environmental resources.

The observed results for LER corroborate with those obtained by RIBEIRO et al. (2017), who studied the agro-economic efficiencies of carrot vs. cowpea intercropping under different spatial arrangements, obtaining higher values in the 2:2 spatial arrangement. Different results were obtained by FAVACHO et al. (2017), who evaluated the agroeconomic efficiencies of carrot vs. cowpea intercropping as a function of $C$. procera biomass quantities and spatial arrangements and observed no statistical difference among the spatial arrangements studied.

In relation to the value observed for the score of the canonical variable $\mathrm{Z}$ of 1.86 , obtained in the 2:2 spatial arrangement, the results are similar 
to those obtained by RIBEIRO et al. (2017), who investigated the agro-economic efficiencies of carrot vs. cowpea intercropping under different spatial arrangements and obtained a higher value in the 2:2 spatial arrangement (1.23).

The values observed for the area-time equivalent ratio (ATER), in the cropping years in the presence of the spatial arrangements were all higher than the unit, presenting biological advantage in land use and in time with the use of these production factors. The results obtained for these factors were all higher than those obtained by DINIZ et al. (2017), who studied the intercropping of palm with sorghum and obtained an ATER value of 1.30.

In the 2:2 spatial arrangement, the values observed for AYL and IA were of 3.13 and 15.92, higher than those reported by CARVALHO et al. (2018), who, when studying the agro-economic return of arugula and carrot intercropping in different spatial arrangements, also obtained higher values with the use of the 2:2 spatial arrangement, obtaining AYL and IA values of 1.06 and 3.56, respectively. Different results were recorded by MORAES et al. (2018), who investigated the competitive and biological ability of the intercropping of beet with cowpea under different green manuring and spatial arrangements, observing a higher AYL value of 0.21 in the $4: 4$ spatial arrangement.

Regarding the highest results obtained for LER, ATER, Z, AYL, and IA of 2.60, 4.16, 2.11, 2.06, and 14.94, respectively, for biomass amounts of 46.42, 47.82, 48.12, 48.57, and $49.09 \mathrm{t} \mathrm{ha}^{-1}$, these findings can be explained by the higher nutrient availability with green manuring, providing higher levels of $\mathrm{N}$ and $\mathrm{K}$.

Another factor related to the use of $M$ aegyptia as green manure is the increased soil organic matter concentration, reducing the retention of $\mathrm{P}$ on the surface of some clay minerals, thereby increasing its plant availability (FAVACHO et al., 2017). However, when $\mathrm{P}$ is limited at the beginning of the vegetative cycle, plant development may be impeded, which is irreversible even at higher P levels in the later developmental stages (GRANT et al., 2001). Thus, this approach may have provided a greater $\mathrm{P}$ availability, resulting in a higher productive capacity.

The LER value of 2.60 indicated that at least an additional area of $1.60 \%$ is needed for crops in monocultures to reach the equivalent of the production of the intercropping system per hectare. This result showed the advantage of the intercropping system in the production of food per unit area, indicating that in this cultivation system, the plants can use the environmental resources more efficiently.

The ATER values above the unit express the agronomic viability of the intercropping system. This index enables a precise determination of the productive advantage of the intercropping system over the monoculture system as it considers the variation in the time spent by the two crops in the intercropping system (AHMED et al., 2017).

The maximum AYL and IA values of 2.06 and 14.94, obtained with M. aegyptia biomass incorporation, portray the viability of this intercropping system as compared to the monoculture. These results are in agreement with the findings of PINTO \& PINTO (2012), who reported that AYL and IA values greater than zero showed the advantage of the intercropping system.

\section{Economic advantage}

The economic advantage of intercropped systems of carrot and cowpea as a function of green manuring and spatial arrangements was assessed through the economic indicators, GI, NI, RR and PM. However, it is known that the economic analysis complements the evaluation of the intercropping systems efficiency, considering besides the physical production of crops, the price of products according to their quality classification and time of the year.

The GI is an indicator that represents the value of crops combined yields in each intercrop system, irrespective of production costs. It depends exactly on the price that the system's production is marketed. On the other hand, the RR is the other indicator that depends on production costs, since it is standardized in terms of those costs. The higher the values of these indicators the more advantage has the intercropping system.

The NI is an indicator that has the advantage of comparing not only the biological efficiency of cropping systems, but also takes into account the fact that inputs, mainly labor, are limited and that they need to be used in different quantities for different cropping systems. It expresses in net terms the value of the biological efficiency free of the production costs. In turn, the PM is another indicator standardized by NI, which expresses in percentage terms the biological efficiency of the intercropping system. The higher the values of these indicators the more net advantage has the intercropping system.

There was no significant interaction between the treatment-factors studied for any economic advantage indicator evaluated (Table 6). However, a significant effect of the cropping years was recorded for all economic indicators, with the 
second cropping year providing higher mean values in GI and NI, in the RR, and PM. On the other hand, there was no significant difference among the spatial arrangements for any of the economic advantage indicators evaluated (Table 6).

An upward polynomial behavior as a function of the increasing amounts of $M$. aegyptia biomass incorporated into the soil was observed for the economic efficiency indicators, registering maximum values of GI, NI, RR, and PM of US\$ $15,929.89 \mathrm{ha}^{-1}$, US\$ 8,720.99 ha $\mathrm{hS}^{-1}$, US 2.21, and $57.55 \%$; respectively, for the green manure amounts of $42.29,32.60,31.51$, and $26.73 \mathrm{t} \mathrm{ha}^{-1}$, with a subsequent decrease (Figures 2A, 2B, 2C, and 2D).

In the second cropping year, we observed the highest values for the indicators of economic advantage, most likely because of the better nutritional conditions, which resulted in a greater productive capacity, a higher green grain yield, and; consequently, a higher economic efficiency of the intercropping system.

Regarding the spatial arrangement, there was no significant difference for the economic performance indicators (GI, NI, RR, and PM), suggesting that the spatial arrangement had no impact on the economic efficiency (Table 6).

However, the maximum values observed (US\$ 15,007.01 ha-1, US\$ 6,887.79 ha ${ }^{-1}$, US\$ 1.90 for each invested dollar, and $44.62 \%$ ) in the $2: 2$ spatial arrangement, compared to previous studies, indicated the higher efficiency of this cropping system (Table 7).

This is confirmed by the values of the economic indicators in the 2:2 spatial arrangement, which were higher than those obtained by CARVALHO et al. (2018), who studied the viability of carrot and arugula intercropping as a function of spatial arrangements, also obtaining higher values in the $2: 2$ spatial arrangement.

The highest values obtained for the economic indicators are due to the fact that the carrot and cowpea plants responded well to green manuring, resulting in a higher economic viability.

The optimal NI (US\$ 8,720.99 $\mathrm{ha}^{-1}$ ) was obtained at a biomass amount of $32.60 \mathrm{t} \mathrm{ha}^{-1}$, indicating the highest economic performance. This is because this economic indicator is more suitable to express the economic value of this cultivation system than the GI, since it deducts the production costs (BEZERRA NETO et al., 2012).

The highest values obtained with $M$. aegyptia biomass in terms of the GI, NI, RR, and $\mathrm{PM}$ in this paper are higher than those obtained by SOUSA et al. (2018), studying the agroeconomic performance of beet association with cowpea with different amounts of $M$. aegyptia biomass; these authors obtained values of US\$ $8,659.79 \mathrm{ha}^{-1}$, US\$ $3,335.30 \mathrm{ha}^{-1}$, US\$ 1.62 for each invested dollar, and $37.86 \%$, respectively.

\section{CONCLUSION}

The highest agro-economic advantages of the carrot and cowpea intercropping were obtained for LER, ATER, NI, and RR of 2.60, 4.16, US\$ 8,720.99 ha $^{-1}$, and US\$ 2.21, respectively, for $M$. aegyptia biomass amounts of 46.42, 47.82, 32.60 and $31.51 \mathrm{t}$ $\mathrm{ha}^{-1}$ added to the soil. The 2: 2 spatial arrangement was the one with the best productive performance, with higher net income and rate of return in the intercropping of carrot-cowpea. The use of M. aegyptia as green manure presents agro-economic feasibility and sustainability in carrot-cowpea intercrops in a

Table 6 - F values and mean values for gross income (GI), net income (NI), rate of return (RR), and profit margin (PM) of carrot intercropped with cowpea in two cropping years under different $M$. aegyptia biomass amounts and spatial arrangements.

\begin{tabular}{|c|c|c|c|c|c|}
\hline Sources of variation & $\mathrm{DF}$ & GI & NI & $\mathrm{RR}$ & PM \\
\hline Blocks (Cropping years) & 6 & $1.14^{\mathrm{ns}}$ & $1.14^{\mathrm{ns}}$ & $1.70^{\mathrm{ns}}$ & $1.70^{\mathrm{ns}}$ \\
\hline Cropping years (Y) & 1 & $12.37^{* *}$ & $12.37^{* *}$ & $13.53^{* *}$ & $11.15^{\mathrm{ns}}$ \\
\hline Amounts of $M$. aegyptia biomass (Q) & 3 & $15.85^{* *}$ & $50.69^{* *}$ & $137.44^{* *}$ & $133.74^{* *}$ \\
\hline Spatial arrangements (A) & 2 & $1.46^{\mathrm{ns}}$ & $0.95^{\mathrm{ns}}$ & $1.39^{\text {ns }}$ & $0.71^{\mathrm{ns}}$ \\
\hline $\mathrm{Y} \times \mathrm{Q}$ & 3 & $0.67^{\text {ns }}$ & $0.67^{\mathrm{ns}}$ & $0.44^{\mathrm{ns}}$ & $0.98^{\text {ns }}$ \\
\hline $\mathrm{Y} \times \mathrm{A}$ & 2 & $0.39^{\text {ns }}$ & $0.39^{\mathrm{ns}}$ & $0.42^{\text {ns }}$ & $0.42^{\text {ns }}$ \\
\hline Q x A & 6 & $0.70^{\text {ns }}$ & $0.63^{\text {ns }}$ & $0.87^{\mathrm{ns}}$ & $0.41^{\mathrm{ns}}$ \\
\hline Y x Q x A & 6 & $1.21^{\mathrm{ns}}$ & $1.21^{\mathrm{ns}}$ & $1.76^{\mathrm{ns}}$ & $1.56^{\mathrm{ns}}$ \\
\hline $\mathrm{CV}(\%)$ & - & 9.56 & 21.21 & 8.53 & 12.32 \\
\hline
\end{tabular}




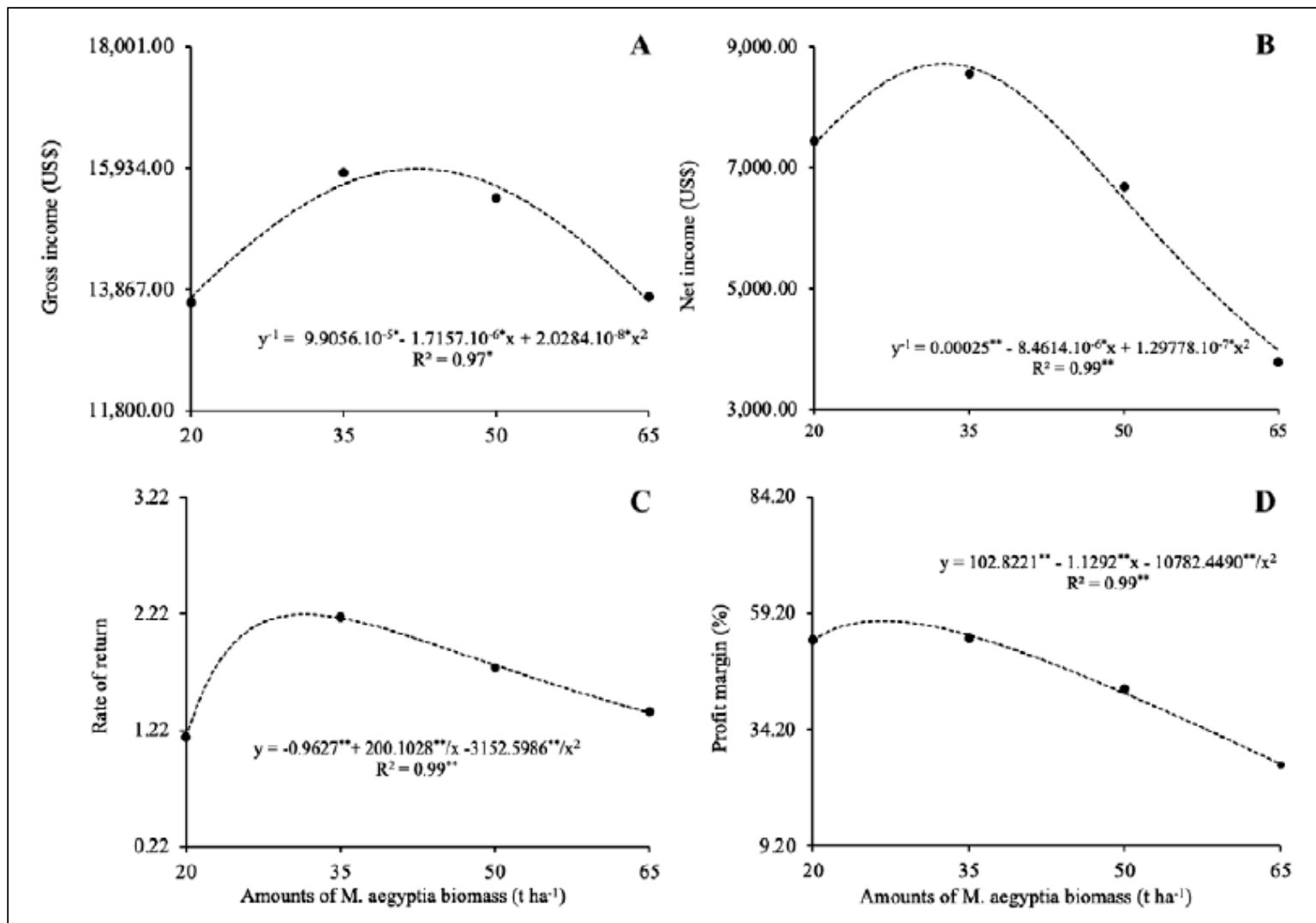

Figure 2 - Gross income (A), net income (B), rate of return (C), and profit margin (D) of the carrot intercropped with cowpea as a function of the amounts of $M$. aegyptia biomass incorporated into the soil.

semi-arid environment. The intercropped systems of vegetable crops have a number of limitations, such as the size of the cultivation area, the appropriate choice of crops for intercropping, the use of cultivars or varieties suitable for the intercropped system, the proper fertilization of the system, the appropriate planting design, the ideal population density by area, the correct sowing in rows and/ or in strips, and not using machinery from planting to harvest and during cultural treatments, among others. However,

Table 7 - Mean values for GI, NI, RR, and PM of carrot intercropped with cowpea in two cropping years and spatial arrangements.

\begin{tabular}{|c|c|c|c|c|}
\hline Cropping years & GI (US\$ ha-1) & NI (US\$ ha-1) & $\mathrm{RR}$ & PM (\%) \\
\hline 1 & $14,159.74 b$ & $6,108.83 b$ & $1.81 \mathrm{~b}$ & $42.32 b^{\dagger}$ \\
\hline 2 & $15,166.49 a$ & $7,115.84 a$ & $1.93 \mathrm{a}$ & $46.03 a$ \\
\hline \multicolumn{5}{|c|}{ 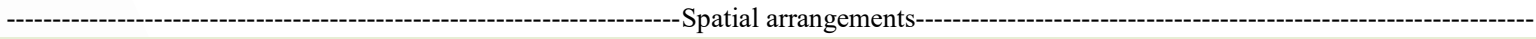 } \\
\hline $2: 2$ & $15,007.01 \mathrm{a}$ & $6,887.79 \mathrm{a}$ & $1.90 \mathrm{a}$ & $44.62 \mathrm{a}$ \\
\hline $3: 3$ & $14,525.97 \mathrm{a}$ & $6,438.18 \mathrm{a}$ & $1.84 \mathrm{a}$ & $43.24 \mathrm{a}$ \\
\hline $4: 4$ & $14,456.62 \mathrm{a}$ & $6,510.91 \mathrm{a}$ & $1.88 \mathrm{a}$ & $44.67 a$ \\
\hline
\end{tabular}

${ }^{* *}=\mathrm{P}<0.01 ; \mathrm{ns}=\mathrm{P} \geq 0.05{ }^{\dagger}$ Means followed by different lowercase letters within one column differ statistically from each other by $\mathrm{F}$ or Tukey test at the $5 \%$ probability level. 
the concern of the farmer regarding the preservation of natural resources, as well as with the search for a better quality of life, circumvents the possible limitations that the environment may offer in a given intercropping crop. The option by intercropping system can provide to producers with viable alternatives to optimize the planted area, increase the biodiversity of the soil microbiota, pest and disease management, in addition to greater productivity and economic stability of activities on the rural property. Therefore, there is a need for research on factors or treatments that evaluate genotypes suitable for the intercropping, sowing time, fertilization, planting spatial arrangement, population densities of the crops, methods of attributing the intercropping's advantage over monocropping and on the vegetable production systems in the different ecosystems where they are implemented.

\section{ACKNOWLEDGEMENTS}

The authors thank to Coordenação de Aperfeiçoamento de Pessoal de Nível Superior - CAPES for its financial support through a doctorate scholarship (PDS: 88882.182030/201801), to the Conselho Nacional de Desenvolvimento Científico e Tecnológico (CNPq Universal 474610/2013-6), to the Universidade Federal Rural do Semi-Árido (UFERSA) for providing with laboratories and experimental areas, and to the research group of the Department of Agronomic and Forestry Sciences of the UFERSA for the development of technologies for growing vegetables on family farms.

\section{DECLARATION OF CONFLICT OF} INTERESTS

The authors declare no conflict of interest. The funding sponsors had no role in the design of the study; in the collection, analyses, or interpretation of data; in the writing of the manuscript, and in the decision to publish the results.

\section{AUTHORS' CONTRIBUTIONS}

The authors contributed equally to the manuscript.

\section{REFERENCES}

ALBUQUERQUE, A. W.; et al. Cover crops and nitrogen fertilization in corn production under no-tillage system. Revista Brasileira de Engenharia Agrícola e Ambiental, v.17, n.7, p.721-726, 2013. Available from: <http://dx.doi.org/10.1590/ S1415-43662013000700005>. Accessed: May, 4, 2019.

AHMED, G. S. H.; et al. Evaluation of competitive indices between roselle and cowpea as influenced by intercropping system and bio-fertilization type. Middle East Journal of Agricultural Research, v.6, n.1, p.199-207, 2017. Available from: $<$ https://www.google.com/search?ei=ugCuXbG7NdCJ5wLtwLqw Ag\&q=scielo+AHMED $\% 2$ C + G.S.H. $\% 3 \mathrm{~B}+$ et + al. + Walid $\% 2 \mathrm{C}+$ N.S. $\% 2$ C + Dalia $\% 2 C+$ N.A.S. $+2017>$. Accessed: May, 4, 2019.
BANIK, P. Evaluation of wheat (Triticum aestivum) and legume intercropping under $1: 1$ and 2:1 row-replacement series system. Journal of Agronomy and Crop Science, v.176, n.5, p.289294, 1996. Available from: <http://dx.doi.org/10.1111/j.1439037X.1996.tb00473.x>. Accessed: May, 4, 2019.

BANIK, P.; et al. Evaluation of mustard (Brassica campestris var. toria) and legume intercropping under $1: 1$ and 2:1 rowreplacement series systems. Journal of Agronomy and Crop Science, v.185, n.1, p.9-14, 2000. Available from: <http:// dx.doi.org/10.1046/j.1439-037X.2000.00388.x>. Accessed: May, 4, 2019.

BEZERRA, F. T. C.; et al. Vegetative behavior and productivity of the sunflower depending on the spatial arrangement of the plants. Revista Ciência Agronômica, v.45, n.2, p.335-343, 2014. Available from: <http://dx.doi.org/10.1590/S180666902014000200015>. Accessed: May, 4, 2019.

BEZERRA NETO, F.; et al. Agronomic and economic optimization of the carrot when fertilized with different dosages of jitarana. Revista Ciência Agronômica, v.45, n.2, p.305311, 2014. Available from: <http://dx.doi.org/10.1590/S180666902014000200011>. Accessed: May, 4, 2019.

BEZERRA NETO, F.; et al. Assessment of agroeconomic indices in polycultures of lettuce, rocket and carrot through uni - and multivariate approaches in semi-arid Brazil. Ecological Indicators, v.14, n.1, p.11-17, 2012. Available from: <http://dx.doi:10.1016/j. ecolind. 2011.07.006>. Accessed: May, 4, 2019.

BRACHTVOGEL, E. L.; et al. Maize plant densities in conventional and equidistant plant spacing. Ciência Rural, v.39, n.8, p.23342339, 2009. Available from: <http://dx.doi.org/10.1590/S010384782009005000193>. Accessed: May, 4, 2019.

CARVALHO, F. W. A.; et al. Optimum plot size of planting and bio-agroeconomic revenues from arugula-carrot intercropping systems in a semi-arid region. Anais da Academia Brasileira de Ciência, v.90, n.4, p.3493-3512, 2018. Available from: $<$ http://dx.doi.org/10.1590/0001-37652018 20170461>. Accessed: May, 4, 2019.

DINIZ, W. J. S.; et al. Forage cactus-sorghum intercropping at different irrigation water depths in the Brazilian semiarid region. Pesquisa Agropecuária Brasileira, v.52, n.9, p.724733, 2017. Available from: <http://dx.doi:10.1590/S0100204X2017000900004>. Accessed: May, 4, 2019.

FAVACHO, F. S.; et al. Productive and economic efficiency of carrot intercropped with cowpea-vegetable resulting from green manure and different spatial arrangements. Revista Ciência Agronômica, v.48, n.2, p.337-346, 2017. Available from: <http://dx.doi:10.5935/1806-6690.2017 0039>. Accessed: May, 4, 2019.

FAVERO, C.; et al. Biomass productivity and nutrient accumulation by spontaneous and leguminous species used for green manure. Revista Brasileira de Ciência do Solo, v.24, n.1, p.171-177, 2000. Available from: <http://dx.doi:10.1590/S010006832000000100019>. Accessed: May, 4, 2019.

FERREIRA, D. F. Sisvar: a computer statistical analysis system. Ciência e Agrotecnologia, v.35, n.6, p.1039-1042, 2011. Available from: $\quad<$ http://dx.doi.org/10.1590/S1413-70542011000600001>. Accessed: May, 4, 2019. 
GRANT, C. A.; et al. The importance of early season phosphorus nutrition. Canadian Journal of Plant Science, v. 81, n. 2, p. 211-224, 2001. $<$ https://doi.org/10.4141/P00-093>. Accessed: Aug. 25, 2020.

JANDEL SCIENTIFIC. Table curve: curve fitting software. Corte Madera,CA:JandelScientific, 1991.280p.Availablefrom: $<$ http://www. scielo.br/scielo.php?script $=$ sci nlinks\&ref $=000074 \&$ pid $=$ S0102$0536200600040001600011 \& \operatorname{lng}=\mathrm{en}>$. Accessed: May, 4, 2019.

MORAES, E. C.; et al. Competitive and biological ability of beet and cowpea vegetable intercropping deriving from green manuring and spatial arrangements. Revista Ceres, v.65, n.5, p.381-388, 2018. Available from: <http://dx.doi.org/ 10.1590/0034-737x2018650 50008>. Accessed: May, 4, 2019.

OLIVEIRA, M. K. T.; et al. Agroeconomic performance of carrot fertilized with scarlet starglory (Merremia aegyptia). Horticultura Brasileira, v.30, n.3, p.433-439, 2012. Available from: <http:// dx.doi:10.1590/S0102-05362012000300013>. Accessed: May, 4, 2019.

PIMENTEL-GOMES, F.; GARCIA, C. H. Estatística aplicada a experimentos agronômicos e florestais: exposição com exemplos e orientações para uso de aplicativos. Piracicaba: FEALQ, 2002. 309p. Available from: <https://bdpi.usp.br/item/001309130>. Accessed: May, 4, 2019.

PINTO, C. M.; PINTO, O. R. O. Evaluation of competitive ability and biological efficiency in intercropping systems. Enciclopédia Biosfera, v.8, n.14, p.105-122, 2012. Available from: <https:// www.google.com $/$ search? source $=$ hp\&ei $=$ GiWuXeiDM965O UPxrCHyAM\&q=PINTO $\% 2 \mathrm{C}+\mathrm{C} . \mathrm{M} . \% 3 \mathrm{~B}+\mathrm{PINTO} \% 2 \mathrm{C}+\mathrm{O} . \mathrm{R}$ .O.+2012>. Accessed: May, 4, 2019.
RÊGO, L. G. S.; et al. Pedogenesis and soil classification of an experimental farm in Mossoró, state of Rio Grande do Norte, Brazil. Revista Caatinga, v.29, n.4, p.10361042, 2016. Available from: <http://dx.doi:10.1590/198321252016v29n430rc>. Accessed: May, 4, 2019.

RIBEIRO, G. M.; et al. Agro-economic efficiency of the intercropping of carrot $\mathrm{x}$ cowpea-vegetable under different spatial arrangements and population densities. Revista Caatinga, v.30, n.4, p.847-854. 2017. Available from: <http:// dx.doi.org/10.1590/1983-21252017v30n404rc>. Accessed: May, 4, 2019.

SILVA, J. N.; et al. Combinations of coriander and salad rocket cultivars in bicropping systems intercropped with carrot cultivars. Revista Caatinga, v.30, n.1, p.125-135, 2017. Available from: $<$ http://dx.doi.org/10.1590/1983-21252017v30n114rc >. Accessed: May, 4, 2019.

SOUSA, D. M.; et al. Agro-economic performance of the association of beet with green cowpea in different amounts of hairy woodrose. Revista Brasileira de Engenharia Agrícola e Ambiental, v.22, n.3, p.194-199, 2018. Available from: <https:// doi.org/10.1590/1807-1929/agriambi.v22n3p194-199>. Accessed: May, 4, 2019.

VIEIRA, F. A.; et al. Bezerra Neto, F., Silva, M.L., Lima, J.S.S., Barros Júnior, A. P., Silva, I.N. 2018. Technicaleconomic efficiency of the yield of green grains of cowpea fertilized with roostertree. Revista Caatinga, v.31, n.2, p.504510, 2018. Available from: <http://dx.doi.org/10.1590/198321252018v31n227rc $>$. Accessed: May, 4, 2019. 